\title{
Viral involvement in the pathogenesis and clinical features of ophthalmic pterygium (Review)
}

\author{
AIKATERINI K. CHALKIA ${ }^{1}$, DEMETRIOS A. SPANDIDOS ${ }^{2}$ and EFSTATHIOS T. DETORAKIS ${ }^{1}$ \\ Departments of ${ }^{1}$ Ophthalmology and ${ }^{2}$ Virology, University Hospital of Heraklion, 71110 Heraklion, Crete, Greece
}

Received June 17, 2013; Accepted July 12, 2013

DOI: $10.3892 / \mathrm{ijmm} .2013 .1438$

\begin{abstract}
Pterygium is a potentially vision-threatening fibrovascular lesion originating from the conjunctiva that often extends on the corneal surface. Although it has been extensively studied, its pathogenesis has yet to be fully elucidated. Recent evidence on molecular genetic abnormalities in pterygium suggested neoplastic changes of limbal stem cells potentially associated with exposure to ultraviolet (UV) light. Human papillomavirus (HPV) is an oncogenic virus, associated with squamo-proliferative lesions of the anogenital region, skin and oropharynx. Several studies have shown HPV involvement in the pathogenesis of conjunctival neoplastic lesions, including papilloma and squamous cell carcinoma. The involvement of HPV as a co-factor in the pathogenesis of pterygium, although suggested by several studies using PCR and immunohistochemical techniques, remains controversial. Moreover, a marked variation in the prevalence of HPV in ophthalmic pterygium has been reported by different studies. Ethnic susceptibility and methodological differences in the detection of HPV may account for this variation. Surgical excision, often using sophisticated techniques, is the standard current method of therapy for pterygium. However, recurrences are frequent and recurrent lesions tend to be more aggressive. If indeed HPV is involved in pterygium pathogenesis or recurrence, anti-viral medications or vaccination may be new options in pterygium therapy.
\end{abstract}

\section{Contents}

1. Introduction

2. Theories of infectious pathogenetic co-factors in pterygium

3. Virus detection in pterygium

4. Current status on HPV detection in pterygium

5. HPV detection in ocular surface lesions

6. Methodologies for HPV detection in pterygium

Correspondence to: Dr Efstathios T. Detorakis, Department of Ophthalmology, University Hospital of Heraklion, 71110 Heraklion, Crete, Greece

E-mail: detorakis@hotmail.com

Key words: pterygium, cornea, HPV, virus, pathogenesis
7. Potential therapeutic interventions in HPV-infected pterygium

8. Conclusion

\section{Introduction}

Pterygium is a wing-shaped fibrovascular lesion of the ocular surface of unknown origin and pathogenesis. It grows at the inter-palpebral conjunctival area, more often nasally, and invades adjacent corneal epithelium (Fig. 1). Pterygium growth can cause irregular astigmatism, corneal scarring, restriction of ocular motility, or chronic ocular surface inflammation (1). Treatment thus far is exclusively surgical, however, pterygium often tends to recur aggressively. This has lead to the use of sophisticated surgical techniques in an effort to reduce recurrence rates (Fig. 2) (2).

Although pterygium pathogenesis remains an enigma, epidemiologic studies suggest that it is a sun-related eye disease (ophthalmoheliosis). In fact, the prevalence of pterygium seems to be associated with geographical latitude, with higher prevalences in areas located within $40^{\circ}$ above and below the equator, suggesting that prolonged exposure to ultraviolet (UV) radiation may promote its development. In addition, repeated micro-trauma, mediated by exposure to dust, chronic conjunctival inflammation, genetic predisposition and ocular dryness have all been reported to be involved in pterygium, indicating a multifactorial pathogenesis $(1,3)$. Evidence suggests that genetically altered limbal epithelial stem cells may play a critical role through a process of Bowman's layer dissolution, matrix remodeling, cell proliferation and angiogenesis, possibly with the involvement of cytokines, matrix metalloproteinases and growth factors (4-10). Notably, among the various theories proposed for pterygium pathogenesis thus far, the possibility of an infectious (probably viral) mechanism in at least a subgroup of pterygia has also recently gained ground. This possibility is important because, should it prove valid, it could justify non-invasive or minimally invasive treatment options through anti-viral medications.

\section{Theories of infectious pathogenetic co-factors in pterygium}

Pterygium has been previously considered a degenerative condition. This hypothesis, however, has been challenged in 
recent years by the detection of important molecular genetic alterations in pterygium, including loss of heterozygosity ( $\mathrm{LOH})$ of microsatellite DNA or the overexpression of mutated versions of $\mathrm{p} 53$ with compromised function, which could promote tumor growth (11-14). Accordingly, a multi-step pathogenetic process, with the participation of genetic inheritance, UV radiation and, importantly, oncogenic viral infection has been proposed for the pathogenesis of pterygium (Fig. 3). According to this 'two-hit' hypothesis, inherited genetic alterations or exposure to environmental factors such as UVR could predispose individuals to this benign neoplastic disease ('first hit'). Oncogenic viruses, or additional UVR exposure, adding further damage to an already susceptible genetic material, may be the stimulus for the outset of development or recurrence of pterygium ('second hit') (15). This theoretical model has been recently supported by the detection of HPV strains considered high-risk for cancer development, including 16 and 18, encoding E6 and E7 proteins which interfere with p53 function $(16,17)$.

\section{Virus detection in pterygium}

Many studies have been conducted to investigate the involvement of a variety of oncogenic viruses, including HPV, CMV, $\mathrm{HSV}$ or EBV, in the development and recurrence of pterygium (Table I). HPV presence in pterygium has been reported by several studies, with prevalence ranging from very low to almost $100 \%$ of cases $(16,18-27)$. The prevalence of various herpes-viruses in pterygium also differs considerably among reports. Studies from Greece detected HSV in $22-45 \%$ and CMV in $40 \%$ of examined pterygia $(18,28)$. On the other hand, in a study conducted in Taiwan Chen et al investigated the role of $\mathrm{HSV}$ in pterygium, where a prevalence of only $5 \%$ was reported (29). Another study from Turkey detected EBV-DNA in $10 \%$ of the pterygia examined (25). Such a disparity in the prevalence of oncogenic virus detection in pterygium may partly be explained by ethnic or geographical factors or by laboratory techniques. However, it may also reflect the heterogeneous nature of pterygium pathogenesis and the possibility that oncogenic viruses affect only a sub-group of ophthalmic pterygia.

\section{Current status on HPV detection in pterygium}

Taking into account that HPV is by far the most commonly reported oncogenic virus associated with ophthalmic pterygium, several studies have focused on HPV detection and typing to assess the potential role HPV plays in the pathogenetic process leading to pterygium development. Of note, certain studies (such as those of Sjö et al from Denmark, Takamura et al from Japan or Hsiao et al from Taiwan) have failed to detect HPV or report very low prevalences of HPV in examined pterygia $(21-23,25,27)$. Moreover, Dushku et al detected p53 overexpression in the limbal epithelium of the pterygia studied with all the samples being negative for HPV DNA, suggesting that factors other than HPV infection were responsible for the p53 overexpression (12). To investigate the role of HPV and the variance in its prevalence in pterygium in the different studies, Piras et al (20) selected patients from two distant geographically populations, Italy and Ecuador. HPV
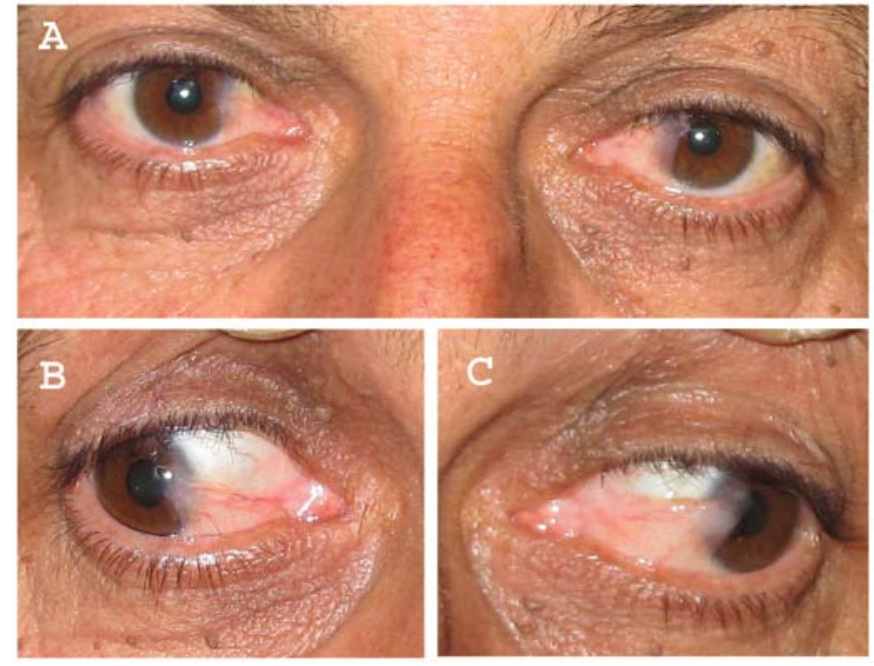

Figure 1. (A) Nasal bilateral pterygium. (B and C) The extent of advancement of the lesions on the corneal surface of the right and left eye is shown on abduction.
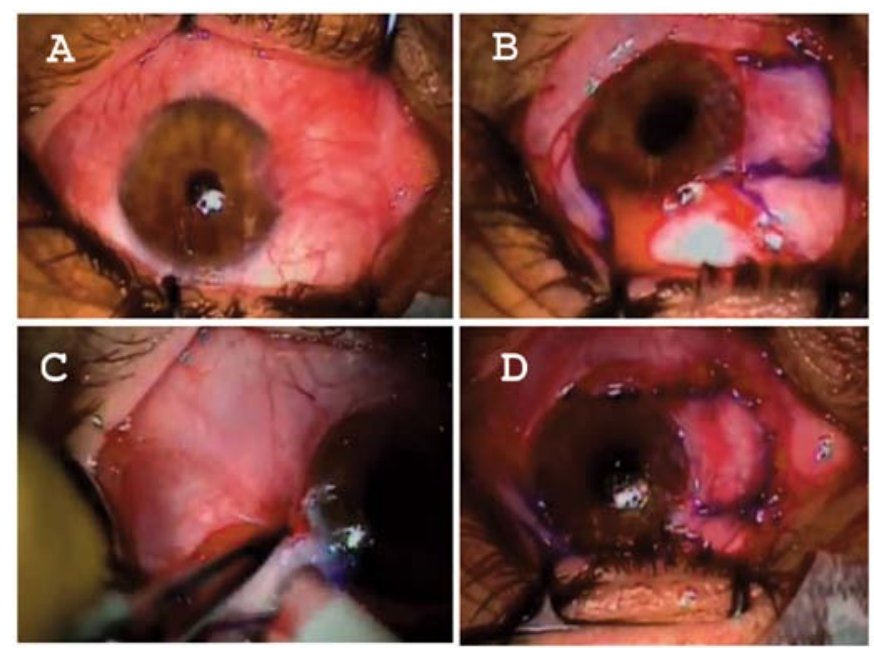

Figure 2. (A) Intraoperative views of nasal and temporal pterygium excision. (B) The nasal pterygium is excised and the defect covered with a conjunctival autograft harvested from the superior bulbar conjunctival area. (C) The temporal pterygium is excised and the defect covered with a locally raised conjunctival flap. (D) Final view at the conclusion of the procedure.

was detected in all the pterygia of Italian patients, but in only $21 \%$ of the pterygia from Ecuador. In that study, geographic and ethnic factors were proposed as a possible explanation for differences in HPV prevalence in pterygium, supporting its multi-factorial pathogenesis (20).

\section{HPV detection in ocular surface lesions}

Over the past three decades HPV DNA has been detected in various ophthalmic lesions of the ocular surface and even in phenotypically normal conjunctiva $(30,31)$. HPV infection has been strongly correlated with the pathogenesis and recurrence of conjunctival papillomas, conjunctival intraepithelial neoplasia (CIN) and even squamous cell carcinoma of the conjunctiva (SCCC) (32-36). HPV may also co-exist in SCCC lesions with other oncogenic viruses, such as HIV, thus it is 
Table I. Prevalence of pterygium-associated viruses in various studies.

\begin{tabular}{|c|c|c|c|c|c|c|c|}
\hline Authors/(Refs.) & $\begin{array}{c}\text { Date of } \\
\text { publication }\end{array}$ & $\begin{array}{c}\text { HPV } \\
\text { prevalence }\end{array}$ & $\begin{array}{c}\text { HSV } \\
\text { prevalence }\end{array}$ & $\begin{array}{c}\text { CMV } \\
\text { prevalence }\end{array}$ & $\begin{array}{c}\text { EBV } \\
\text { prevalence }\end{array}$ & $\begin{array}{l}\text { Country of } \\
\text { the study }\end{array}$ & $\begin{array}{l}\text { Method of } \\
\text { detection }\end{array}$ \\
\hline Spandidos, et al (28) & 1994 & - & $45 \%$ & $40 \%$ & $0 \%$ & Greece & PCR \\
\hline Detorakis, et al (18) & 2001 & $\begin{array}{c}24 \% \\
\text { (Type 18) }\end{array}$ & $22 \%$ & - & - & Greece & PCR \\
\hline Gallagher, et al (19) & 2001 & $\begin{array}{c}50 \% \\
\text { (Types 6,11,16) }\end{array}$ & - & - & - & UK & PCR \\
\hline Piras, et al (20) & 2003 & $\begin{array}{c}100 \% \\
21 \% \\
\text { (Types 52, 54, } \\
\text { cand } \text { HPV90, unknown) }\end{array}$ & - & - & - & $\begin{array}{c}\text { Italy } \\
\text { Equador }\end{array}$ & $\begin{array}{c}\text { PCR- } \\
\text { sequencing }\end{array}$ \\
\hline Schellini, et al (21) & 2006 & $0 \%$ & - & - & - & Brazil & PCR \\
\hline Sjö, et al (34) & 2007 & $\begin{array}{c}4.4 \%{ }^{\mathrm{a}} \\
\text { (Type 6) }\end{array}$ & - & - & - & Denmark & PCR-ISH \\
\hline Chen, et al (29) & 2008 & - & $5 \% \mathrm{a}$ & - & - & Taiwan & PCR-ISH \\
\hline Takamura, et al (23) & 2008 & $4.8 \%^{\mathrm{b}}$ & - & - & - & Japan & PCR-HC II \\
\hline Rodrigues, et al (24) & 2008 & $\begin{array}{c}58.3 \% \\
\text { (Types } 1,2,16)\end{array}$ & & & & Brazil & PCR \\
\hline Otlu, et al (25) & 2009 & $0 \%$ & - & - & $10 \%$ & Turkey & Real-time PCR \\
\hline Tsai, et al (16) & 2009 & $\begin{array}{c}24 \% \\
\text { (Types } 16,18)\end{array}$ & $\begin{array}{l}- \\
-\end{array}$ & $\begin{array}{l}- \\
-\end{array}$ & $\begin{array}{l}- \\
-\end{array}$ & $\begin{array}{l}\text { Taiwan } \\
\text { Poland }\end{array}$ & $\begin{array}{c}\text { Nested-PCR } \\
\text { PCR }\end{array}$ \\
\hline Piecyk-Sidor, et al (26) & 2009 & $\begin{array}{c}27.6 \% \\
\text { (Types 5, 6, 11, } \\
16,18,31,52,59)\end{array}$ & & & & & \\
\hline Hsiao, et al (27) & 2010 & $\begin{array}{c}3 \% \\
\text { (Type 18) }\end{array}$ & - & - & - & Taiwan & PCR-ISH \\
\hline
\end{tabular}

avirus-DNA negative with ISH; ${ }^{b} \mathrm{HPV}-\mathrm{DNA}$ negative with Hybrid Capture II.

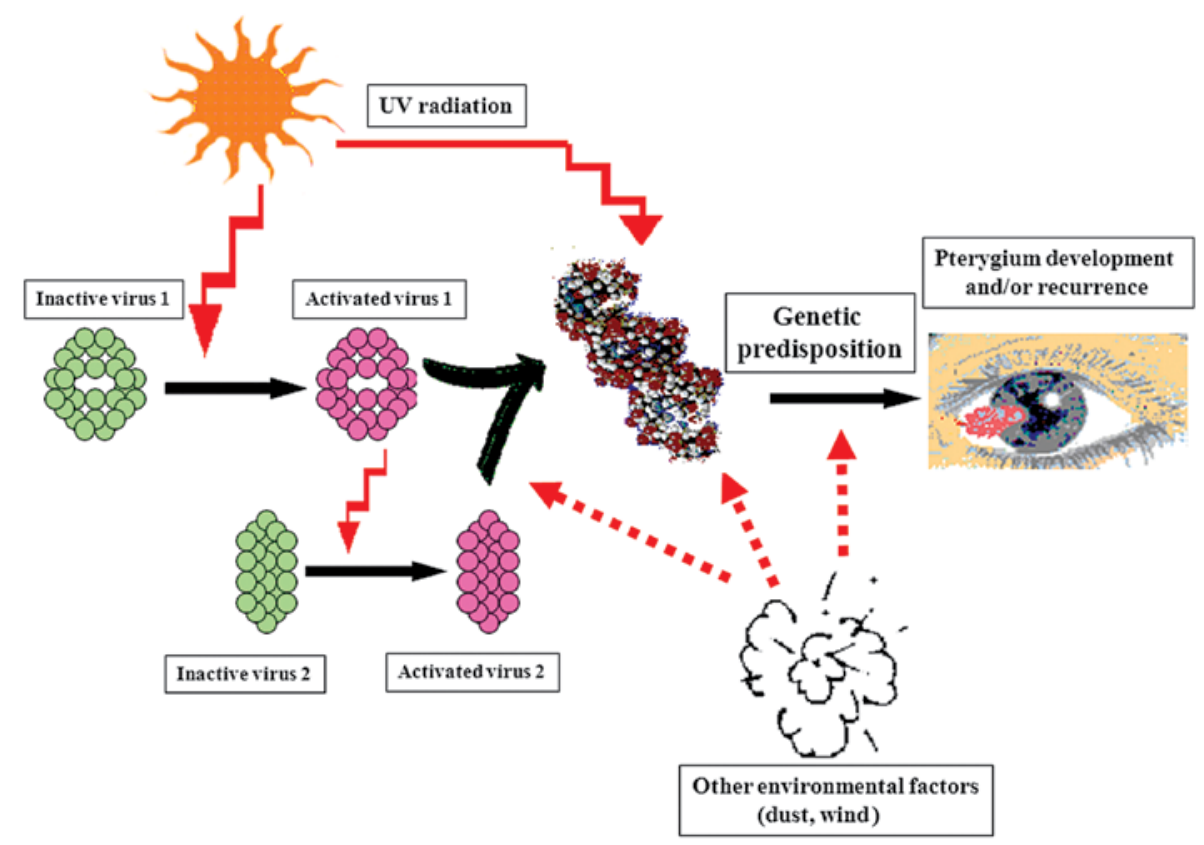

Figure 3. A proposed multi-step model for pterygium pathogenesis, in which genetic predisposition, viral involvement and environmental factors co-participate (adapted from ref. 15). 
difficult to determine the importance of HPV per se in the development of these lesions (36). The fact that pterygium has also often been reported to co-exist with ocular surface neoplastic lesions $(37,38)$, supports the hypothesis of oncogenic viral infection or co-operation as a pathogenetic model. Obtaining cells from the ocular surface via non-invasive methodologies, including exfoliation cytology techniques (39), may enable the detection of HPV-infected pterygia.

\section{Methodologies for HPV detection in pterygium}

HPVs are non-enveloped viruses with icosahedral symmetry, composed of a circular double-stranded DNA genome. HPVs cause infections of the skin and the mucous membranes of the anogenital region and the oropharynx. Over 100 types have been fully sequenced and some seem to play an important role in the development of tumors. According to their oncogenic potential, HPVs are divided into low- and high-risk types (oncogenic/ high-risk types: $16,18,31,33,35,39,45,51,52,56,58,59,68$, $73,82$ and potentially oncogenic types: $26,53,66)(17,40,41)$.

Diagnosis of the viral infection is based on the detection of the HPV-DNA. However, the mode of sample collection, the quantity of the HPV-DNA of the isolated sample and the use of various HPV-DNA detection techniques with different sensitivity and specificity, are factors that may significantly affect the detection rates of HPV infections (40).

HPV-DNA can be directly isolated from a biopsy specimen with in situ hybridization (ISH), Southern blotting and dot blot hybridization. However, these techniques are laborious, need a large quantity of purified DNA and their sensitivity is limited (40).

In cases where the biopsy specimen is small with a limited quantity of HPV-DNA, nucleic acid amplification assays can be used to increase the sensitivity and specificity of the test. Hybrid Capture II (HC-II) is a non-radioactive signal amplification technique, accurate for mucosal lesions, that distinguishes high-risk from low-risk HPV-types, but is not appropriate for genotyping (40-42).

Due to its high sensitivity, polymerase chain reaction (PCR) is frequently associated with a high rate of false-positive results (43). Southern blot, dot blot, reverse dot blot, digestion with restriction endonucleases or direct sequence analysis performed after DNA amplification can help increase the sensitivity and specificity of the test $(41,42)$. Real-time PCR or quantitative PCR (qPCR) permits rapid detection and quantification of the viral load during the various cycles of the PCR process (real-time) (43). Reverse transcriptase-PCR (RT-PCR) is a qualitative assay that permits the identification of viral gene expression with the use of reverse transcriptase. The combination of the two techniques, quantitative RT-PCR or real-time RT-PCR (qRT-PCR), is considered to be the first choice assay for the detection of viral gene expression as it combines quantitative and qualitative advantages of the two methods $(44,45)$.

\section{Potential therapeutic interventions in HPV-infected pterygium}

Current treatment of pterygium includes surgical excision and occasionally adjunctive therapy. Several surgical techniques have been described: bare sclera closure, sliding conjunc- tival flaps, use of autologous conjunctival and limbal grafts or amniotic membranes $(2,46)$ (Fig. 2). Due to the possible complications and costs of surgical treatment and the risk of recurrence, often aggressive, various adjunctive therapies have been proposed, including $\beta$-irradiation and the use of mitomycin $\mathrm{C}$ or 5 -fluorouracil. However these methods have been associated with corneoscleral necrosis and melting, limbal stem cell deficiency and variable recurrence rates. B-irradiation has also been associated with cataract formation $(2,46)$.

Interferons are a family of proteins with antiviral, antiproliferative, antiangiogenetic and immunomodulatory properties, produced from the organism in response to various stimuli (47). The recombinant form $\alpha-2 b$ (IFN- $\alpha-2 b$ ) has been used for the treatment of condylomata acuminata, chronic hepatitis B and $\mathrm{C}$, Kaposi sarcoma, malignant melanoma, hairy cell leukemia and follicular lymphoma (47). Unlike mitomycin C and 5-fluorouracil, adverse effects associated with the topical or sub-conjunctival administration of IFN- $\alpha-2 b$ are less severe (48-52). IFN- $\alpha-2 b$ in the form of eye drops has successfully been used thus far in the management of CIN and conjunctival papilloma (48-51). IFN- $\alpha-2 b$ has also been reported to prevent the recurrence of pterygium (52). However, additional investigation is required to fully assess the value of this treatment modality in the treatment of pterygium.

\section{Conclusion}

Despite controversies in the medical literature concerning HPV involvement in pterygium (possibly due to racial susceptibility or methodological differences), most studies agree that HPV is detected in at least a sub-group of pterygia and that HPV infection may affect both pathogenesis and clinical behaviour (including recurrence) of these lesions. Accordingly, it would be interesting to explore the possibility of anti-viral medications or even vaccination, which may represent novel options in the therapy of selected, HPV-infected pterygia.

\section{References}

1. Detorakis ET and Spandidos DA: Pathogenetic mechanisms and treatment options for ophthalmic pterygium: Trends and perspectives (Review). Int J Mol Med 23: 439-447, 2009.

2. Hirst LW: The Treatment of pterygium. Surv Ophthalmol 48: 145-180, 2003.

3. Coroneo MT: Pterygium as an early indicator of ultraviolet insolation: a hypothesis. Br J Ophthalmol 77: 734-739, 1993.

4. Chui J, Coroneo MT, Tat LT, Crouch R, Wakefield D and Di Girolamo N: Ophthalmic pterygium: a stem cell disorder with premalignant features. Am J Pathol 178: 817-827, 2011.

5. Detorakis ET, Zaravinos A and Spandidos DA: Growth factor expression in ophthalmic pterygia and normal conjunctiva. Int $\mathbf{J}$ Mol Med 25: 513-516, 2010.

6. Di Girolamo N, Wakefield D and Coroneo MT: Differential expression of matrix metalloproteinases and their tissue inhibitors at the advancing pterygium head. Invest Ophthalmol Vis Sci 41: 4142-4149, 2000.

7. Tsai YY, Chiang CC, Yeh KT, Lee H and Cheng YW: Effect of TIMP-1 and MMP in pterygium invasion. Invest Ophthalmol Vis Sci 51: 3462-3467, 2010

8. Aspiotis M, Tsanou E, Gorezis S, Ioachim E, Skyrlas A, Stefaniotou M and Malamou-Mitsi V: Angiogenesis in pterygium: study of microvessel density, vascular endothelial growth factor, and thrombospondin-1. Eye (Lond) 21: 1095-1101, 2007.

9. Solomon A, Li DQ, Lee SB and Tseng SC: Type plasminogen activator in primary pterygium body fibroblasts by inflammatory cytokines. Invest Ophthalmol Vis Sci 41: 2154-2163, 2000. 
10. Solomon A, Grueterich M, Li DQ, Meller D, Lee SB and Tseng SC: Overexpression of insulin-like growth factor-binding protein-2 in pterygium body fibroblasts. Invest Ophthalmol Vis Sci 44: 573-580, 2003.

11. Detorakis ET, Sourvinos G, Tsamparlakis J and Spandidos DA: Evaluation of loss of heterozygosity and microsatellite instability in human pterygium: clinical correlations. Br J Ophthalmol 82: 1324-1328, 1998.

12. Dushku N, Hatcher SL, Albert DM and Reid TW: P53 expression and relation to human papillomavirus infection in pingueculae, pterygia, and limbal tumors. Arch Ophthalmol 117: 1593-1599, 1999.

13. Soussi T, Dehouche K and Béroud C: P53 website and analysis of P53 gene mutations in human cancer: forging a link between epidemiology and carcinogenesis. Hum Mutat 15: 105-113, 2000

14. Freed-Pastor WA and Prives C: Mutant p53: one name, many proteins. Genes Dev 26: 1268-1286, 2012.

15. Detorakis ET, Drakonaki EE and Spandidos DA: Molecular genetic alterations and viral presence in ophthalmic pterygium. Int J Mol Med 6: 35-41, 2000.

16. Tsai YY, Chang CC, Chiang CC, Yeh KT, Chen PL, Chang $\mathrm{CH}$, Chou MC, Lee H and Cheng YW: HPV infection and p53 inactivation in pterygium. Mol Vis 15: 1092-1097, 2009.

17. Burk RD, Chen Z and Van Doorslaer K: Human papillomaviruses: genetic basis of carcinogenicity. Public Health Genomics 12: 281-290, 2009.

18. Detorakis ET, Sourvinos G and Spandidos DA: Detection of herpes simplex virus and human papilloma virus in ophthalmic pterygium. Cornea 20: 164-167, 2001.

19. Gallagher MJ, Giannoudis A, Herrington CS and Hiscott P: Human papillomavirus in pterygium. Br J Ophthalmol 85: 782-784, 2001.

20. Piras F, Moore PS, Ugalde J, Perra MT, Scarpa A and Sirigu P: Detection of human papillomavirus DNA in pterygia from different geographical regions. Br J Ophthalmol 87: 864-866, 2003.

21. Schellini SA, Hoyama E, Shiratori CA, Sakamoto RH and Candeias JM: Lack of papillomavirus (HPV) in pterygia of a Brazilian sample. Arq Bras Oftalmol 69: 519-521, 2006.

22. Sjö NC, von Buchwald C, Prause JU, Norrild B, Vinding T and Heegaard S: Human papillomavirus and pterygium. Is the virus a risk factor? Br J Ophthalmol 91: 1016-1018, 2007.

23. Takamura Y, Kubo E, Tsuzuki S and Akagi Y: Detection of human papillomavirus in pterygium and conjunctival papilloma by hybrid capture II and PCR assays. Eye (Lond) 22: 1442-1445, 2008.

24. Rodrigues FW, Arruda JT, Silva RE and Moura KK: Polymorphism and human papillomavirus DNA associated with pterygium. Genet Mol Res 7: 1251-1258, 2008.

25. Otlu B, Emre S, Turkcuoglu P, Doganay S and Durmaz R: Investigation of human papillomavirus and Epstein-Barr virus DNAs in pterygium tissue. Eur J Ophthalmol 19: 175-179, 2009.

26. Piecyk-Sidor M, Polz-Dacewicz M,Zagórski Z and Zarnowski T: Occurrence of human papillomavirus in pterygia. Acta Ophthalmol 87: 890-895, 2009.

27. Hsiao CH, Lee BH, Ngan KW, Chuang WY, Yeung L, Yeh LK, Tan HY, Hui-Kang D and Lin KK: Presence of human papillomavirus in pterygium in Taiwan. Cornea 29: 123-127, 2010.

28. Spandidos D, Xinarianos G, Ergazaki M, Giannoudis A and Tsamparlakis $\mathrm{J}$ : The presence of herpesviruses in pterygium. Int J Oncol 5: 749-752, 1994.

29. Chen YF, Hsiao CH, Ngan KW, Yeung L, Tan HY, Yang KH, Huang SC and Lin KK: Herpes simplex virus and pterygium in Taiwan. Cornea 27: 311-313, 2008.

30. Karcioglu ZA and Issa TM: Human papilloma virus in neoplastic and non-neoplastic conditions of the external eye. Br J Ophthalmol 81: 595-598, 1997.

31. McDonnell JM, McDonnell PJ and Sun YY: Human papillomavirus DNA in tissues and ocular surface swabs of patients with conjunctival epithelial neoplasia. Invest Ophthalmol Vis Sci 33: 184-189, 1992.
32. Saegusa M, Takano Y, Hashimura M, Okayasu I and Shiga J: HPV type 16 in conjunctival and junctional papilloma, dysplasia, and squamous cell carcinoma. J Clin Pathol 48: 1106-1110, 1995.

33. Sjö NC, Heegaard S, Prause JU, von Buchwald C and Lindeberg H: Human papillomavirus in conjunctival papilloma. Br J Ophthalmol 85: 785-787, 2001.

34. Sjö NC, von Buchwald C, Cassonnet P, Norrild B, Prause JU, Vinding $\mathrm{T}$ and Heegaard S: Human papillomavirus in normal conjunctival tissue and in conjunctival papilloma: types and frequencies in a large series. Br J Ophthalmol 91: 1014-1015, 2007.

35. Kiire CA and Dhillon B: The aetiology and associations of conjunctival intraepithelial neoplasia. Br J Ophthalmol 90: 109-113, 2006.

36. Ateenyi-Agaba C, Franceschi S, Wabwire-Mangen F, Arslan A, Othieno E, Binta-Kahwa J, van Doorn LJ, Kleter B, Quint W and Weiderpass E: Human papillomavirus infection and squamous cell carcinoma of the conjunctiva. Br J Cancer 102: 262-267, 2010.

37. Hirst LW, Axelsen RA and Schwab I: Pterygium and associated ocular surface squamous neoplasia. Arch Ophthalmol 127: 31-32, 2009.

38. Artornsombudh P, Sanpavat A, Tinnungwattana U, Tongkhomsai V, Sansopha L and Tulvatana W: Prevalence and clinicopathologic findings of conjunctival epithelial neoplasia in pterygia. Ophthalmology 120: 1337-1340.

39. Bandyopadhyay R, Nag D, Mondal SK, Gangopadhyay S, Bagchi K and Bhaduri G: Ocular surface disorder in pterygium: role of conjunctival impression cytology. Indian J Pathol Microbiol 53: 692-695, 2010.

40. Abreu AL, Souza RP, Gimenes F and Consolaro ME: A review of methods for detect human Papillomavirus infection. Virol J 9: 262,2012

41. Molijn A, Kleter B, Quint W and van Doorn LJ: Molecular diagnosis of human papillomavirus (HPV) infections. J Clin Virol 32 (Suppl 1): S43-S51, 2005.

42. Leto Md, Santos Júnior GF, Porro AM and Tomimori J: Human papillomavirus infection: etiopathogenesis, molecular biology and clinical manifestations. An Bras Dermatol 86: 306-317, 2011 (In English, Portuguese).

43. Mackay IM: Real-time PCR in the microbiology laboratory. Clin Microbiol Infect 10: 190-212, 2004.

44. Bustin SA, Benes V, Nolan T and Pfaffl MW: Quantitative real-time RT-PCR - a perspective. J Mol Endocrinol 34: 597-601, 2005.

45. Jensen EC: Real-time reverse transcription polymerase chain reaction to measure mRNA: use, limitations, and presentation of results. Anat Rec (Hoboken) 295: 1-3, 2012.

46. Todani A and Melki SA: Pterygium current concepts in pathogenesis and treatment. Int Ophthalmol Clin 49: 21-30, 2009.

47. Jonasch $E$ and Haluska FG: Interferon in oncological practice: review of interferon biology, clinical applications, and toxicities. Oncologist 6: 34-55, 2001.

48. Vann RR and Karp CL: Perilesional and topical interferon alfa-2b for conjunctival and corneal neoplasia. Ophthalmology 106: 91-97, 1999.

49. Karp CL, Moore JK and Rosa RH Jr: Treatment of conjunctival and corneal intraepithelial neoplasia with topical interferon alpha-2b. Ophthalmology 108: 1093-1098, 2001.

50. Schechter BA, Schrier A, Nagler RS, Smith EF and Velasquez GE: Regression of presumed primary conjunctival and corneal intraepithelial neoplasia with topical interferon alpha-2b. Cornea 21: 6-11, 2002.

51. Schechter BA, Rand WJ, Velazquez GE, Williams WD and Starasoler L: Treatment of conjunctival papillomata with topical interferon Alfa-2b. Am J Ophthalmol 134: 268-270, 2002.

52. Esquenazi S: Treatment of early pterygium recurrence with topical administration of interferon alpha-2b. Can J Ophthalmol 40: 185-187, 2005. 